\title{
PELAKSANAAN AKAD TABARRU, PADA ASURANSI SYARIAH (Studi di Takaful Indonesia Cabang Malang)
}

\author{
Dwi Fidhayanti \\ Fakultas Syari'ah UIN Maulana Malik Ibrahim Malang \\ Email:fidha.shi@gmail.com
}

\begin{abstract}
Abstrak
This study aims at analyzing tabarru' concept based on The Sharia National Council of Fatwa No.53/ DSN-MUI/III/2006 in Islamic Insurance and Islamic Reinsurance. Research method which is applied in this research is qualitative research and data are collected through interviews and documentation. Data are analyzed by descriptive method. The results shows that the implementation of the tabarru' agreement in Takaful Indonesia has been accordance with a Sharia National Council of fatwa about tabarru'agreement in Islamic Insurance and Islamic Reinsurance. However, there is a gap of tabarru' agreement between theory and reality contained in the Takaful Indonesia, namely the existence of a refund system contributions (tabarru' funds and ujrah) that have been given when it unilaterally terminated the agreement by the participants before the period of the agreement runs out. It should not be practiced because tabarru' agreement is similar with the grant.

Penelitian ini bertujuan untuk menganalisa konsep tabarru'berdasarkan Fatwa Dewan Syariah Nasional No.53/DSN-MUI/III/2006 pada Asuransi Syariah dan Reasuransi Syariah. Metode penelitiannya yang digunakan adalah kualitatif dan data dikumpulkan melalui wawancara dan dokumentasi. Data dianalisa dengan menggunakan metode analisis data deskriptif. Hasil penelitian menunjukkan bahwa pelaksanaan akad tabarru' pada Takaful Indonesia sesuai dengan fatwa Dewan Syariah Nasional tentang Akad Tabarru' pada Asuransi Syariah dan Reasuransi Syariah. Namun, terdapat kesenjangan mengenai akad tabarru' antara teori dengan realita yang terdapat pada Takaful Indonesia, yaitu mengenai adanya sistem pengembalian dana kontribusi (dana tabarru'dan ujrah) yang telah diberikan ketika perjanjian diputus secara sepihak oleh peserta sebelum periode perjanjian habis, seharusnya hal ini tidak boleh dilakukan karena Akad Tabarru'sama dengan hibah.
\end{abstract}

Kata Kunci: Akad Tabarru', Asuransi Syariah

Indonesia merupakan negara yang memiliki umat muslim terbesar di dunia. Dibanding dengan pemeluk agama lain di Indonesia. Prosentase pemeluk Islam lebih tinggi, yaitu sebesar $88 \%$. Besarnya umat muslim di Indonesia dapat mendukung pertumbuhan perekonomian di Indonesia, khususnya perekonomian yang berbasis syariah. Pertumbuhan dan perkembangan perbankan syariah di Indonesia ditandai dengan berdirinya Bank Muamalat pada 1 Nopember 1991.Berdirinya BankMuamalatkemudian menginspirasi berdirinya bank-bank syariah. Kajian mengenai ekonomi syariah dan perbankan syariah terus dikembangkan sehingga turut menumbuhkan lembaga keuangan syariah seperti asuransi syariah, pasar modal syariah, pegadaian syariah, lembaga pembiayaan syariah dan pengelolaan dana pensiun.
Salah satu lembaga keuangan syariah yang dapat tubuh dan berkembang dengan baik di Indonesia adalah asuransi syariah. Banyak pengguna jasa asuransi syariah tidak hanya berasal dari umat muslim, tetapi juga dari kalangan non-muslim. Alasan kalangan muslim maupun non-muslim memilih asuransi syariah adalah adanya sistem yang lebih transparan dan adil dalam asuransi syariah. Adanya sistem tersebut membuat minat masyarakat terhadap asuransi syariah menjadi meningkat. Minat masyarakat yang begitu tinggi terhadap asuransi syariah inilah yang kemudian mendorong berbagai perusahaan masuk dalam bisnis asuransi syariah, di antaranya dilakukan dengan langsung mendirikan perusahaan asuransi syariah secara penuh maupun membuka divisi atau cabang 
asuransi syariah. ${ }^{1}$ Banyaknya pengusaha yang membuka usaha asuransi membuat pertumbuhan asuransi syariah seimbang dengan Asuransi konvensional dengan prosentase $50 \%-50 \%$.

Tujuan utama dari adanya asuransi adalah untuk meminimalisir setiap resiko tidak terduga yang terjadi pada setiap individu maupun kelompok. Risiko dapat dikatakan sebagai elemen kehidupan di dunia yang tidak dapat diketahui oleh manusia. ${ }^{2}$ Oleh karena itu, Islam mengajarkan umat muslim untuk bekerja keras dan berusaha untuk meminimalisir resiko-resiko yang kemungkinan akan terjadi dalam hidupnya. Hal ini bertujuan agar umat muslim dapat mengubah kondisi mereka, seperti yang terdapat dalam Firman Allah QS. Ar-Ra'ad:11:

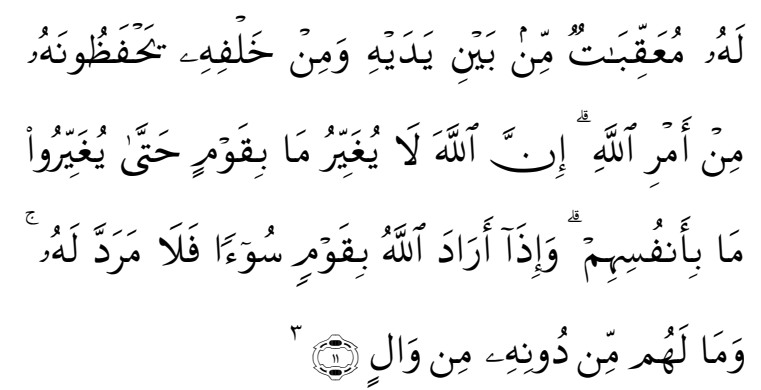

"Bagi manusia ada malaikat-malaikat yang selalu mengikutinya bergiliran, di muka dan di belakangnya, mereka menjaganya atas perintah Allah. Sesungguhnya Allah tidak merubah Keadaan sesuatu kaum sehingga mereka merubah keadaan yang ada pada diri mereka sendiri. dan apabila Allah menghendaki keburukan terhadap sesuatu kaum, Maka tak ada yang dapat menolaknya; dan sekali-kali tak ada pelindung bagi mereka selain Dia."

Dalam asuransi syariah atau takaful terdapat dua akad utama yang digunakan, yaitu akad tijarah dan akad tabarru'. Akad tijarah adalah segala bentuk akad yang dilakukan untuk tujuan komersial. Sementara, akad tabarru' adalah semua bentuk akad yang dilakukan dengan tujuan kebaikan dan tolong-menolong, kebalikan dari akad tijarah.

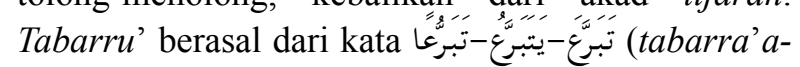
yatabarra'u-tabarru'an) yang berarti sumbangan, hibah, dana kebajikan atau derma. ' Akad tabarru' merupakan akad yang mendasari asuransi syariah

\footnotetext{
1 "Sejarah Asuransi Syariah di Indonesia", www.asuransisyariah.net, diakses tanggal 19 Oktober 2011.

2 "Risk Management in Islam-Takaful", www.islamic-world.net, diakses tanggal 13 Mei 2011.

3 QS. Ar-Ra'ad (13):11, 370.

4 Muhammad Syakir Sula, Asuransi Syariah (Life And General): Konsep Dan System Operasional, cet.1 (Jakarta: Gema Insani Press, 2004), h. 35.
}

karena akad tersebut harus melekat pada semua produk asuransi syariah. Setiap peserta asuransi syariah memberikan dana tabarru' kepada pengelola asuransi kemudian dana tersebut akan dikumpulkan dalam satu akun tabarru' yang terpisah dari akun dana-dana lain yang terdapat pada asuransi syariah. Dana tabarru' ini boleh digunakan oleh siapa saja yang mendapatkan musibah. Sementara, asuransi syariah merupakan lembaga professional yang mempunyai tujuan komersil, maka dana tabarru' ini hanya terbatas pada peserta asuransi syariah.

Pada akad tabarru' terjadi perpindahan kepemilikan harta dari pemberi kepada penerima secara sukarela tanpa berniat mencari keuntungan dan tidak menuntut penggantian. Tujuannya adalah tolongmenolong sehingga peserta asuransi syariah hanya mengharap pahala dari Allah SWT. Berbeda dengan akad mu'awadhah pada asuransi konvensional, pihak yang memberikan sesuatu berhak mendapatkan penggantian dari pihak yang diberi. Teori tersebut tidak sesuai dengan teori murni dari akad tabarru' yang menyatakan bahwa akad tabarru' tidak boleh ada pengembalian. Akan tetapi, secara praktek peserta dalam akad tabarru' mempunyai peran ganda, yaitu peserta sebagai pemberi dana tabarru' dan peserta sebagai pihak yang berhak menerima dana tabarru'. Dengan adanya peran ganda tersebut, peserta yang memberikan dana tabarru' secara tidak langsung mengharapkan adanya penggantian apabila suatu saat ia mengalami musibah karena dana tabarru' yang diberikan merupakan hak peserta.

Ketidaksesuaian antara teori dan praktek yang demikian dapat menunjukkan bahwa terdapat kesenjangan pada akad tabarru' dalam asuransi syariah. Secara teoritis akad tabarru' tidak membolehkan adanya pengembalian, akan tetapi secara praktek pada asuransi syariah peserta boleh mendapatkan pengembalian dana tabarru' apabila tidak terjadi klaim melalui surplus underwriting. Sementara, apabila terjadi klaim, peserta juga berhak atas dana tabarru' yang diambil dari kumpulan dana tabarru' peserta.

Yusuf Qardhawi mengartikan tabarru' sama dengan hibah. ${ }^{5}$ Apabila dana tabarru' yang telah diberikan kemudian ditarik kembali, tidak ada bedanya dengan menarik kembali hibah yang telah diberikan kepada orang lain. ${ }^{6}$ Ajaran Islam tidak memper-

\footnotetext{
5 Yusuf Qardhawi, al-Halal wal-haram fil-Islam, diterjemahkan Abu Sa'id alFalahi dan Aunur Rafiq Shaleh Tamhid, Halal dan Haram dalam Islam (Cet. I; Jakarta: Rabbani Press, 2000), h. 317.

6 Ma'ruf Amin, Solusi Berasuransi: Lebih Indah dengan Syariah (Jakarta: Salamadani, 2009), h. 76.
} 
bolehkan hal yang demikian, sebagaimana sabda Rasulullah SAW yang diriwayatkan oleh Ibnu Abbas r.a.,:

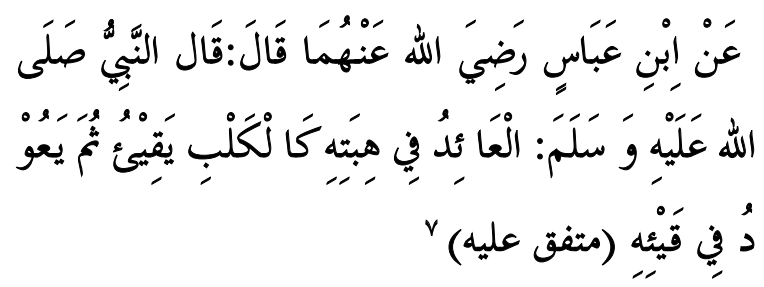

"orang yang meminta kembali sesuatu yang telah dihibahkan/diberikan kepada orang lain, adalah sama dengan seekor anjing yang muntah kemudian memakan kembali muntahannya tersebut."

Adanya kesenjangan antara teori akad tabarru' dengan praktek pada asuransi syariah menarik perhatian penelit. Hal ini dikarenakan, meskipun asuransi syariah merupakan lembaga professional yang profit oriented seharusnya tidak merubah teori murni dari setiap akad sehingga pelaksanaan asuransi syariah sesuai dengan prinsip syariah yang sebenarnya.

Dalam penelitian ini peneliti menggunakan fatwa Dewan Syariah Nasional No.53/DSN-MUI/III/2006 tentang Akad Tabarru' Pada Asuransi Syariah dan Reasuransi Syariah sebagai alat untuk menganalisis pelaksanaan dari akad tabarru' di Takaful Indonesia cabang Malang. Dengan penggunaan fatwa No.53/ DSN-MUI/III/2006 tentang Akad Tabarru' Pada Asuransi Syariah dan Reasuransi Syariah sebagai alat untuk menganalisis, maka dapat diketahui kesesuaian antara pelaksanaan dari akad tabarru' di Takaful Indonesia cabang Malang dengan ketentuan-ketentuan yang terdapat pada fatwa Dewan Syariah Nasional No.53/DSN-MUI/III/2006 tentang Akad Tabarru' Pada Asuransi Syariah dan Reasuransi Syariah. Selain itu, juga dapat diketahui apakah praktek yang ada di Takaful Indonesia Cabang Malang berjalan sesuai dengan prinsip syariah.

Pada penelitian ini, peneliti melakukan penelitian yang intensif pada perusahaan asuransi syariah bernama Takaful Indonesia cabang Malang. Peneliti memilih perusahaan asuransi Takaful Indonesia karena merupakan pelopor asuransi syariah di Indonesia. ${ }^{8}$ Alasan lain peneliti memilih Takaful Indonesia cabang Malang sebagai lokasi penelitian adalah karena Takaful Indonesia merupakan pelopor asuransi syariah di Indonesia yang menerapkan prinsip murni syariah sehingga peneliti tertarik me-

\footnotetext{
7 M. Nashiruddin al-Albani, Ringkasan Shahih Muslim, diterjemahkan Elly Latifah (cet. IV; Depok: Gema Insani, 2008), h. 467.

8 "Sekilas Takaful Indonesia", www.takaful.com, diakses pada tanggal 19 Oktober 2011
}

lakukan penelitian mengenai pelaksanaan akad tabarru' murni yang terdapat di Takaful Indonesia. Perusahaan ini bernama PT Syarikat Takaful Indonesia yang terdiri dari PT Asuransi Takaful Keluarga dan PT Asuransi Takaful Umum. Takaful Indonesia berdiri sejak 24 Februari 1994 dan telah memperoleh sertifikat ISO 9001:2000 dari SGS JASANZ, Selandia Baru bagi Asuransi Takaful Umum. Sementara, Asuransi Takaful Keluarga memperoleh Sertifikat ISO 9001:2000 dari dari Det Norske Veritas (DNV), Belanda pada April 2004. adanya sertifikasi ISO tersebut dapat membuktikan bahwa Takaful Indonesia merupakan perusahaan asuransi syariah yang handal di Indonesia.

Penelitian ini diharapkan mampu menjelaskan kesesuaian akad tabarru' baik secara teori maupun praktek seiring dengan berkembangnya usaha perasuransian di Indonesia dan dapat bermanfaat bagi umat Islam agar memahami akad tabarru' yang ada dalam asuransi syariah sehingga bertambah kepercayaannya bahwa perusahaan asuransi syariah dapat mengelola dana tabarru' dengan benar sesuai prinsip syariah khususnya sesuai dengan fatwa Dewan Syariah Nasional No.53/DSN-MUI/III/2006 tentang Akad Tabarru' pada Asuransi Syariah dan Reasuransi Syariah.

\section{Metode Penelitian}

Jenis penelitian yang digunakan merupakan penelitian empiris atau non-doktrinal, yaitu hukum dikonsepsikan sebagai pranata riil dikaitkan dengan variable-variabel sosial yang lain..$^{9}$ Objek kajian penelitian empiris adalah fakta sosial. ${ }^{10}$ Peneliti melakukan penelitian untuk melihat penerapan akad tabarru' sebagai suatu pola yang dilakukan secara terus menerus dalam masyarakat atau disebut sebagai pranata riil. Penelitian ini menggunakan pendekatan kualitatif yang bersifat deskriptif, yaitu penelitian yang menghasilkan prosedur analisis yang tidak menggunakan analisis statistik atau penelitian yang didasarkan pada upaya membangun pandangan yang diteliti dengan rinci, dibentuk dengan kata-kata atau gambaran holistik. ${ }^{11}$

Terdapat dua sumber data yang digunakan, yaitu data yang diperoleh secara langsung dari sumber utama seperti perilaku warga masyarakat

\footnotetext{
9 Amiruddin dan Zainal Asikin, Pengantar Metode Penelitian Hukum (Jakarta Rajawali Press, 2006), h. 133.

10 Bahder Johan Nasution, Metode Penelitian Hukum (Bandung: Mandar Maju, 2008), h. 82 .

11 Lexy J. Moleong, Metode Penelitian Kualitatif, Edisi Revisi (Bandung: PT Remaja Rosdakarya, 2005), h. 6.
} 
yang dilihat melalui penelitian ${ }^{12}$ dan data sekunder yang merupakan data-data yang dikumpulkan, diolah dan disajikan oleh pihak lain. Metode pengumpulan data yang digunakan dalam penelitian ini berupa wawancara berencana dan studi dokumen. Wawancara berencana (standardized interview), yaitu wawancara yang disertai dengan daftar pertayaan yang telah disusun sebelumnya. Sedangkan, studi dokumen meliputi studi bahan-bahan hukum yang bertujuan untuk memeriksa ulang validitas dan reliabilitas yang dapat menentukan hasil dari suatu penelitian. ${ }^{13}$

Untuk mengecek keabsahan data pada penelitian ini digunakan salah satu metode triangulasi, yaitu dengan cara membandingkan hasil wawancara dengan isi suatu dokumen yang berkaitan. ${ }^{14}$ Hasil wawancara mengenai pelaksanaan akad tabarru' yang dilakukan dengan pelaksana Takaful Indonesia cabang Malang dibandingkan dengan fatwa Dewan Syariah Nasional No.53/DSN-MUI/III/2006 tentang Akad Tabarru“ pada Asuransi Syariah dan Reasuransi Syariah sehingga diperoleh suatu hasil yang dapat menunjukkan perbedaan maupun kesesuaian penerapan dari akad tabarru' dengan fatwa Dewan Syariah Nasional No.53/DSN-MUI/III/2006 tentang Akad Tabarru Dalam Asuransi Syariah dan Reasuransi Syariah di Takaful Indonesia cabang Malang.

\section{Hasil dan Pembahasan}

Takaful Indonesia merupakan pelopor asuransi syariah di Indonesia. Takaful Indonesia telah melayani masyarakat dengan jasa asuransi yang sesuai dengan prinsip-prinsip murni syariah. PT Syarikat Takaful Indonesia (Perusahaan) berdiri pada 24 Februari 1994. Pendirian PT Syarikat Takaful Indonesia (Perusahaan) diprakarsai oleh Tim Pembentukan Asuransi Takaful Indonesia (TEPATI) yang dimotori oleh Ikatan Cendekiawan Muslim Indonesia (ICMI) melalui Yayasan Abdi Bangsa, Bank Muamalat Indonesia Tbk., PT Asuransi Jiwa Tugu Mandiri, Departemen Keuangan RI, serta beberapa pengusaha muslim Indonesia. PT Asuransi Takaful Keluarga yang bergerak di bidang asuransi jiwa Syariah didirikan pada 4 Agustus 1994. Perusahaan ini kemudian beroperasi pada 25 Agustus 1994, yang ditandai dengan peresmian oleh Menteri Keuangan Mar'ie Muhammad. Dalam perkembangannya, PT Syarikat Takaful Indonesia (Perusahaan) juga mendirikan anak perusahaan lain

\footnotetext{
12 Soerjono Soekanto, Pengantar Penelitian Hukum (cet. Ke-3, Jakarta: UI Press, 1986), h. 12.

13 Amiruddin dan Zainal Azikin, Pengantar, h. 68.

14 Lexy J. Moleong, Metode, h. 330.
}

yang bergerak di bidang asuransi umum Syariah, yaitu PT Asuransi Takaful Umum, yang diresmikan oleh Menristek/Ketua BPPT Prof. Dr. B.J. Habibie pada 2 Juni 1995.

Di tahun 2004, Perusahaan melakukan restrukturisasi yang berhasil menyatukan fungsi pemasaran Asuransi Takaful Keluarga dan Asuransi Takaful Umum sehingga lebih efisien serta lebih efektif dalam penetrasi pasar, juga diikuti dengan peresmian kantor pusat, Graha Takaful Indonesia di Mampang Prapatan, Jakarta pada Desember 2004. Untuk meningkatkan kualitas layanan yang diberikan perusahaan dan menjaga konsistensinya, Perusahaan memperoleh sertifikat ISO 9001:2000 dari SGS JASANZ, Selandia Baru bagi Asuransi Takaful Umum dan untuk Asuransi Takaful Keluarga juga memperoleh Sertifikat ISO 9001:2000 dari Det Norske Veritas (DNV), Belanda pada April 2004. ${ }^{15}$

Visi dari Takaful Indonesia adalah menjadi grup asuransi terkemuka yang menawarkan jasa Takaful dan keuangan syariah yang komprehensif dengan jangkauan signifikan di seluruh Indonesia. Produk-produk dari takaful umum meliputi Takaful Baituna, Takaful Surgaina, Takaful Abror, Takaful Ansor, Takaful Rekayasa, Takaful Aneka, Takaful Kebakaran, Takaful Pengangkutan \& Rangka Kapal, Takaful Kendaraan Bermotor. ${ }^{16}$

\section{Kesesuaian Pelaksanaan Akad Tabarru' Di Takaful Indonesia Cabang Malang Dengan Fatwa Dewan Syariah Nasional}

Karakter utama dari asuransi syariah adalah adanya unsur tolong-menolong antar peserta asuransi. Tolong-menolong dalam asuransi syariah diwujudkan dalam bentuk memberikan dana tabarru'. Dana tabarru' ini yang digunakan untuk menolong peserta lain yang sedang mengalami musibah. Menurut Yusuf Qardhawi dalam bukunya Halal dan Haram dalam Islam. tabarru' pada hakikatnya sama dengan hibah, ${ }^{17}$ pihak yang telah memberikan dana tabarru' tidak boleh mengambilnya kembali. Sebagian besar jumhur ulama mengharamkan mengambil kembali hibah yang telah diberikan, kecuali hibah seorang bapak kepada anaknya. ${ }^{18}$

Dana tabarru' yang diserahkan kepada pengelola harus diiringi dengan niat ikhlas untuk tujuan tolong-menolong tanpa adanya harapan untuk

\footnotetext{
15 "Sekilas Takaful Indonesia", www.takaful.com diakses tanggal 7 Maret 2012.

16 "Produk", www.takaful.com, diakses tanggal 15 Februari 2012.

17 Yusuf Qardhawi, al-Halal, h. 317.

18 Al Imam Al Hafizh Ibnu Hajar Al Asqalani, Fathul, h. 452.
} 
mendapatkan imbalan atas apa yang telah diberikan. Peserta hanya mengharapkan imbalan pahala dari Allah SWT.

Dalam mengharap pahala dari Allah SWT, maka setiapumatmuslimberusahauntuk menjalankan ajaran Islam secara sempurna tidak hanya dalam bidang ibadah tetapi juga dalam bidang muamalah. Majelis Ulama Indonesia melalui Dewan Syariah Nasional melakukan pengawasan terhadap pelaksanaan kegiatan ekonomi syariah. Pengawasan tersebut dapat memberikan dampak yang besar terhadap Lembaga Keuangan Syariah untuk tetap berjalan sesuai dengan prinsip syariah. Dewan Syariah Nasional dalam mengawasi pelaksanaan akad tabarru' agar sesuai dengan prinsip syariah mengeluarkan fatwa Dewan Syariah Nasional No. 53/DSN-MUI/III/2006 tentang Akad Tabarru' pada Asuransi Syariah dan Reasuransi Syariah. Dari hasil wawancara dengan Bapak Ahmad Zainul Hasan, S.H, beliau menegaskan bahwa ${ }^{19}$ :

"Sejak awal didirikan, Takaful Indonesia sudah menggunakan Fatwa Dewan Syariah Nasional sebagai pedoman dalam melaksanakan asuransi syariah, begitu pula fatwa Dewan Syariah Nasional No. 53/DSN-MUI/III/2006 tentang Akad Tabarru' pada Asuransi Syariah dan Reasuransi Syariah juga telah diterapkan oleh Takaful Indonesia."

Produk yang terdapat pada Takaful Indonesia terdiri dari dua produk utama, yaitu produk Asuransi Takaful Keluarga dan Asuransi Takaful Umum. Menurut Muhammad Syafi'i Antonio seperti yang dikutip oleh Gemala Dewi, Asuransi Takaful keluarga adalah produk takaful yang memberikan perlindungan dalam menghadapi musibah kematian dan kecelakaan atas diri peserta dan keluarga. Sementara, Asuransi Takaful umum adalah produk takaful yang fokus utamanya memberikan layanan dan bantuan dalam bidang kerugian. ${ }^{20}$

Produk-produk dari Asuransi Takaful Umum terdiri dari Takaful Baituna, Takaful Surgaina, Takaful Abror, Takaful Ansor, Takaful Rekayasa, Takaful Aneka, Takaful Kebakaran, Takaful Pengangkutan dan Rangka Kapal, serta Takaful Kendaraan Bermotor. Penelitian ini berfokus pada Takaful Kendaraan Bermotor dan Takaful Kebakaran. Dari kedua produk ini dapat diketahui bahwa semua produk dari Asuransi Takaful Umum mengandung akad tabarru'. Dalam beberapa polis dari produk-produk Asuransi Takaful Umum, tabarru' dapat dilihat pada alokasi dari kontribusi yang harus dibayarkan oleh peserta.

19 Ahmad Zainul Hasan, Wawancara (Malang, 8 Februari 2012). 20 "Produk", www.takaful.co.id, diakses tanggal 15 Februari 2012.
Bapak Ahmad Zainul Hasan, S.H menjelaskan bahwa ${ }^{21}$ :"Komposisi dari dana tabarru' yang dibayarkan peserta terdiri dari ujrah untuk pengelola $40 \%$ dan sisanya sebesar $60 \%$ untuk cadangan tabarru'."

Dana tabarru' tidak hanya ada pada produk Asuransi Takaful Umum, akan tetapi juga ada pada produk Asuransi Takaful Keluarga. Pada Takaful Indonesia terdapat satu produk unik yang mengandung tabarru', akan tetapi produk tersebut dapat dijadikan sebagai produk Asuransi Takaful Umum maupun Produk Asuransi Takaful Keluarga. Bapak Ahmad Zainul Hasan, S.H pada saat sesi wawancara menjelaskan mengenai produk tersebut. Beliau menyatakan bahwa ${ }^{22}$ :

"Pada Takaful Indonesia, terdapat satu produk yang mengandung unsur tabarru', akan tetapi produk tersebut bisa masuk pada produk Asuransi Takaful Umum atau pun produk Asuransi Takaful Keluarga. Produk tersebut disebut dengan personal accident. Produk personal accident mengandung unsur tabarru' apabila produk tersebut masuk pada Asuransi Takaful Umum dan apabila masuk pada Asuransi Takaful Keluarga produk tersebut bisa ditambah dengan unsur saving."

Akad tabarru' telah digunakan pada semua produk Asuransi Takaful Umum sehingga dapat dikatakan bahwa Takaful Indonesia telah menerapkan ketentuan angka 1 bagian pertama dari ketentuan hukum fatwa Dewan Syariah Nasional No. 53/DSNMUI/III/2006 tentang Akad Tabarru' pada Asuransi Syariah dan Reasuransi Syariah yang menyatakan bahwa akad tabarru' merupakan akad yang harus melekat pada semua produk asuransi. Hal ini sesuai dengan pendapat dari Muhammad Syakir Sula yang menyatakan bahwa akad tabarru' merupakan akad yang mendasari kontrak asuransi syariah. ${ }^{23}$

Pada asuransi syariah setiap peserta yang bergabung dengan asuransi syariah mempunyai niat untuk menolong dan melindungi sesama peserta yang sedang tertimpa musibah. Usaha untuk saling menolong dan melindungi diantara para peserta tersebut dilakukan dengan cara menyisihkan sebagian dananya sebagai kontribusi kebajikan yang disebut tabarru'.

Pada Takaful Indonesia, akad tabarru' dilakukan hanya terbatas pada peserta pemegang polis. Hal ini

\footnotetext{
21 Ahmad Zainul Hasan, Wawancara (Malang, 8 Februari 2012). 22 Ahmad Zainul Hasan, Wawancara (Malang, 8 Februari 2012). 23 Muhammad Syakir Sula, Asuransi, h. 226.
} 
dikarenakan Takaful Indonesia merupakan lembaga profesional yang bertujuan untuk mencari keuntungan. Praktek bahwa akad tabarru' dilakukan antar peserta pemegang polis dapat dilihat dari tata cara pengajuan klaim. Misalnya klaim untuk Takaful Kendaraan Bermotor, Bapak Mashudi, S.E sebagai underwriting staff menjelaskan mengenai tata cara pengajuan klaim pada produk tersebut ${ }^{24}$ :

\section{"Untuk mengajukan klaim pada Takaful Umum misalnya untuk produk Takaful Kendaraan bermotor harus memenuhi persyaratan seperti Fotocopy polis; STNK; SIM; Mengisi form kerugian; Foto saat kecelakaan; dan Foto emoxy, yaitu foto ketika kendaraan tersebut sedang diperbaiki."}

Salah satu dari persyaratan yang disebutkan oleh bapak Mashudi, S.E menentukan bahwa syarat untuk mengajukan klaim, yaitu peserta harus memberikan fotocopy polis. Polis dapat dijadikan bukti bahwa seseorang tersebut benar merupakan peserta dari Asuransi Takaful Umum. Di dalam polis terdapat kesepakatan antara peserta dengan pengelola mengenai objek yang di-cover serta manfaat yang akan didapatkan ketika peserta tersebut sedang mengalami musibah. Setelah persyaratan diatas dapat terpenuhi maka kantor cabang akan mengirim data-data tersebut ke kantor pusat yang berada di Surabaya dan klaim akan dibayarkan oleh kantor pusat langsung kepada bengkel rekanan melalui rekening kantor pusat, bukan dari kantor cabang.

Praktek pada Takaful Indonesia tersebut sesuai dengan ketentuan angka 2 bagian pertama dari ketentuan hukum fatwa Dewan Syariah Nasional No. 53/DSN-MUI/III/2006 tentang Akad Tabarru' pada Asuransi Syariah dan Reasuransi Syariah yang menyebutkan bahwa akad tabarru' pada asuransi adalah semua bentuk akad yang dilakukan antar peserta pemegang polis. Polis merupakan bukti autentik berupa akta yang mengenai adanya perjanjian asuransi antara peserta asuransi dengan perusahaan asuransi. ${ }^{25}$ Menurut Mohd. Fadzli Yusof seperti yang dikutip oleh Muhammad Syakir Sula, secara umum tabarru' mempunyai pengertian yang luas. Dana tabarru' boleh digunakan untuk menolong siapa saja yang terkena musibah, akan tetapi karena menggunakan akad khusus maka kemanfaatnya terbatas

\footnotetext{
24 Mashudi, Wawancara (Malang, 15 Februari 2012).

25 Andri Soemitra, Bank dan Lembaga Keuangan Syariah (Jakarta:Prenada Media Grup, 2009), h. 275.
}

pada peserta takaful saja. Apabila dana tabarru' digunakan untuk kepentingan lain, ini berarti telah melanggar ketentuan akad.

Ketentuan akad angka 1 dari fatwa Dewan Syariah Nasional tentang Akad Tabarru'padaAsuransi Syariah dan Reasuransi Syariah menyebutkan bahwa Akad tabarru' pada asuransi adalah akad yang dilakukan dalam bentuk hibah dengan tujuan kebajikan dan tolong-menolong antar peserta, bukan untuk tujuan komersial. Berdasarkan hasil wawancara dengan bapak Ahmad Zainul Hasan, S.H selaku pimpinan Takaful Indonesia, beliau mendeskripsikan tabarru'sebagai berikut ${ }^{26}$ :

'Tabarru' adalah dana hibah atau dana kebajikan yang kemudian dikontribusikan untuk membantu peserta lain yang mengalami musibah."

Pengertian tabarru' yang disebutkan oleh Bapak Ahmad Zainul Hasan, S.H secara substansial sama dengan pengertian tabarru ' yang terdapat pada fatwa Dewan Syariah Nasional No. 53/DSN-MUI/III/2006 tentang Akad Tabarru' pada Asuransi Syariah dan Reasuransi Syariah. Yusuf Qardhawi mengartikan tabarru'sama dengan hibah. Tabarru'secara fiqhiyah juga masuk dalam kategori akad hibah. Dalam salah satu definisi hibah disebutkan bahwa:

$$
\text { الهبة بالمعنى العام هي تبرع بمال لمصلحة الغير حال }
$$

"Hibah dalam pengertian umum adalah bertabarru' dengan harta untuk kemashlahatan orang lain dalam kondisi hidup.

Jadi, dapat dikatakan bahwa dana tabarru'yang merupakan akad hibah apabila telah diberikan tidak boleh diambil kembali. Perumpamaannya sebagaimana sabda Rasulullah SAW yang diriwayatkan oleh Ibnu Abbas r.a.,:

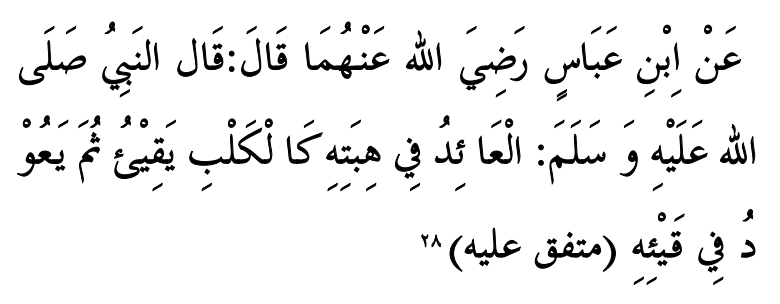

"orang yang meminta kembali sesuatu yang telah dihibahkan/diberikan kepada orang lain, adalah

\footnotetext{
26 Ahmad Zainul Hasan, Wawancara (Malang, 8 Februari 2012).

27 Ma'ruf Amin, Solusi Berasuransi, h. 71.

28 M. Nashiruddin al-Albani, Ringkasan, h. 467.
} 
sama dengan seekor anjing yang muntah kemudian memakan kembali muntahannya tersebut."

Sifat dari perumpamaan yang terdapat dalam hadits tersebut sangat buruk. Oleh karena itu tidak baik bagi seorang muslim untuk mensifati dirinya dengan sifat yang buruk sehingga disamakan dengan hewan yang paling buruk pada saat kondisinya yang terburuk. $^{29}$

Apabila hibah telah diberikan maka tidak boleh diambil kembali. Hal berbeda dilakukan oleh Takaful Indonesia, yang mana Takaful Indonesia menerapkan sistem pengembalian. Pengembalian dilakukan ketika terjadi dua hal, yaitu selama periode polis tidak terjadi klaim dan pada saat perjanjian diputus secara sepihak oleh peserta sebelum periode perjanjian habis. Pengembalian ketika selama periode polis tidak terjadi klaim bukan diambil dari dana tabarru' yang telah diberikan. Menurut Bapak Ahmad Zainul Hasan, S.H $\mathrm{H}^{30}$ :

'Berkaitan dengan dana tabarru' tindakan yang dilakukan takaful apabila hingga jangka waktu perjanjian berakhir tidak ada klaim, maka peserta bisa memperoleh dana yang berasal dari surplus underwriting dana tabarru'. Karena tabarru' sama dengan hibah sehingga tabarru'yang telah diberikan tidak boleh diambil kembali oleh peserta. Jadi, pengembalian yang diberikan peserta bukan berasal dari dana tabarru'yang yang diberikan selama masa perjanjian, melainkan dari surplus underwriting dana Tabarru'."

Dana tabarru' yang mengalami surplus underwriting tersebut merupakan hak peserta secara individu karena berasal dari hasil investasi dana tabarru' yang telah diberikan setelah dikurangi untuk cadangan tabarru' dan fee atau ujrah untuk pengelola yang telah mewakili peserta untuk mengelola dana tabarru' tersebut. Praktek pada Takaful Indonesia yang memberikan pengembalian dari surplus underwriting dana tabarru' sesuai dengan teori yang dikemukakan oleh Yusuf Qardhawi yang melarang adanya pengembalian dari dana tabarru' yang telah diberikan.

Sementara itu, pengembalian juga diberikan oleh pengelola ketika perjanjian diputus secara sepihak oleh peserta sebelum periode perjanjian habis. Bapak Mashudi, S.E menjelaskan mengenai pengem-balian ketika perjanjian diputus secara sepihak oleh

29 Al Imam Al Hafizh Ibnu Hajar Al Asqalani, Fathul, h. 452 30 Ahmad Zainul Hasan, Wawancara (Malang, 8 Februari 2012). peserta sebelum periode perjanjian habis sebagai berikut ${ }^{31}$ :"Ketika perjanjian putus sebelum periode perjanjian berakhir, peserta akan mendapatkan pengembalian yang jumlahnya ditentukan dari periode yang telah dilewati dan jumlah premi yang telah dibayarkan."

Hal ini akan berbeda ketika selama perjanjian peserta tidak dapat membayarkan kontribusi, Takaful Indonesia tetap mengharuskan peserta untuk membayar kontribusi sebesar $20 \%$ dari premi satu tahun. Tidak dapat diketahui secara pasti alasan Takaful Indonesia memberikan pengembalian karena kantor cabang Malang tidak menjalankan tugas yang sifatnya fital dalam perusahaan. Kantor cabang hanya berwenang terhadap nasabah baru dan pelaporan klaim. Pengembalian tabarru' yang telah diserahkan oleh peserta tidak sesuai dengan teori yang menyatakan bahwa tabarru' sama dengan hibah. Hal ini dikarenakan dana tabarru' yang telah diberikan seharusnya tidak boleh ditarik kembali.

Berdasarkan hukum Islam, apabila dengan alasan yang logis debitur tidak dapat memenuhi kewajibannya tepat waktu, maka debitur harus diberikan waktu untuk menyelesaikan kewajiban tersebut. Muhammad Syakir Sula dalam bukunya menyarankan bahwa ketentuan tersebut juga harus berlaku pada peserta yang dengan alasan tertentu tidak dapat membayar kontribusi sesuai dengan waktu yang telah disepakati. Peserta harus diberi waktu untuk bisa membayar kontribusi sesuai dengan syarat dan ketentuan yang disepakati. Namun, apabila peserta gagal menyelesaikannya, polis dapat dibatalkan. Kontribusi yang sudah dibayarkan dikembalikan kepada peserta dengan pembagian keuntungan yang dibuat atas kontribusi yang dibayarkan setelah dikurangi biaya untuk pengelola. ${ }^{32}$

Menurut angka 2 mengenai ketentuan akad dalam fatwa Dewan Syariah Nasional menyebutkan bahwa dalam akad tabarru', harus disebutkan sekurang-kurangnya: a) Hak dan kewajiban masingmasing peserta secara individu; b) Hak dan kewajiban antara peserta secara individu dalam akun tabarru " selaku peserta dalam arti badan/kelompok; c) Cara dan waktu pembayaran premi dan klaim; d) Syaratsyarat lain yang disepakati, sesuai dengan jenis asuransi yang diakadkan.

Praktek pada Takaful Indonesia, akad tabarru " dituangkan dalam bentuk polis. Di dalam polis berisi

31 Mashudi, Wawancara (Malang, 15 Februari 2012).

32 Muhammad Syakir Sula, Asuransi, h. 248. 
identitas peserta, jangka waktu manfaat takaful, kontribusi, cara pembayaran, objek yang di-cover, pengecualian-pengecualian, dan klausula-klausula seperti klausula resiko non-pasar, klausula bank, klausula penghentian polis takaful, klausula pengembalian surplus tabarru' dan klausula penerapan akad wakalah bil ujrah dan tabarru'.

Pada Takaful Indonesia dana hibah atau dana tabarru' disebut dengan dana kontribusi. Dana kontribusi yang terdapat pada Asuransi Takaful Umum dialokasikan untuk ujrah bagi pengelola $40 \%$ dan untuk cadangan tabarru' sebesar $60 \%$. Dana cadangan tabarru'yang dibayarkan oleh para peserta dimasukkan dalam pool of tabarru'yang kemudian digunakan untuk membantupeserta lainyang sedang mengalamimusibah. Hal ini sesuai dengan ketentuan ketiga mengenai kedudukan para pihak dalam akad tabarru' angka 1 dari fatwa Dewan Syariah Nasional No. 53/DSN-MUI/ III/2006 tentang Akad Tabarru' pada Asuransi Syariah dan Reasuransi Syariah yang menyatakan bahwa dalam akad tabarru', peserta memberikan dana hibah yang akan digunakan untuk menolong peserta atau peserta lain yang tertimpa musibah.

Berikut ini merupakan hadits yang menunjukkan arti saling menanggung, saling melindungi, dan saling tolong menolong antar muslim:

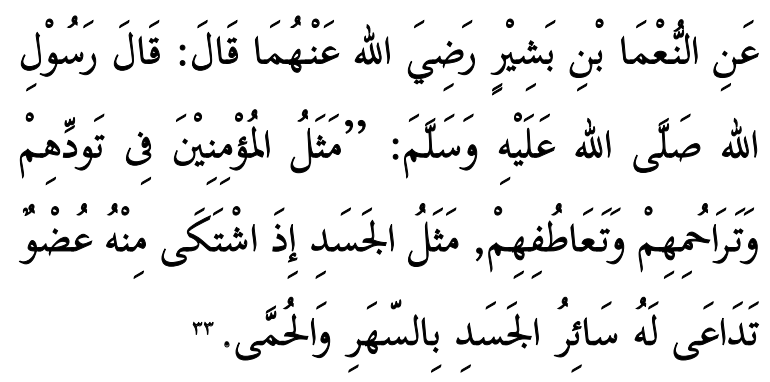

"An-Nu'man bin Basyir mengatakan bahwa Rasulullah SAW bersabda: "orang-orang dalam hal saling mencintai, saling menyayangi bagaikan satu tubuh. Apabila ada sebagian tubuh yang sakit, maka seluruh tubuh tidak bisa tidur dan turut merasakan sakitnya."

Hadis di atas menjelaskan bahwa sesama muslim apabila muslim yang satu merasakan sakit, maka muslim yang lain tidak bisa tidur dan juga merasakan sakit. Untuk itu, diajurkan untuk saling membantu antar sesama muslim ibaratnya ketika muslim lain mengalami kesususahan, maka yang turut merasa susah sehingga timbul rasa iba dan mempunyai keinginan untuk menolong.

33 M. Nashiruddin al-Albani, Ringkasan, h. 906.
Hal ini akan berbeda ketika dalam angka 2 mengenai kedudukan Para pihak dalam akad tabarru' pada fatwa Dewan Syariah Nasional tentang Akad Tabarru' pada Asuransi Syariah dan Reasuransi Syariah yang menyebutkan bahwa Peserta secara individu merupakan pihak yang berhak menerima dana tabarru' (mu'amman/mutabarra' lahu, مؤ من له dan secara kolektif selaku penanggung (mu'ammin/mutabarri', مؤ من/ متبرع). Peserta yang bergabung dengan asuransi syariah, dalam hal ini adalah Takaful Indonesia mempunyai niat untuk membantu sesama peserta yang sedang mengalami musibah dengan menjadi penanggung (mu'ammin/ mutabarri', مؤ من/ متبرع) yang secara kolektif dengan peserta lain mengumpulkan dana tabarru'. Dana tabarru' merupakan hak peserta, peserta itu sendiri secara tidak langsung pada awal bergabung menjadi peserta di Takaful Indonesia niat awalnya justru bukan untuk tujuan tolong menolong dengan mengikhlaskan dana tabarru' untuk menolong peserta lain, akan tetapi niatnya adalah ketika peserta tersebut mendapatkan musibah maka peserta bisa mendapatkan uang pertanggunggan yang secara sah merupakan hak peserta. Jika demikian, maka tidak ada bedanya antara asuransi syariah dengan asuransi konvensional yang bersifat mu'awadhah. Pada akad yang bersifat mu'awadhah pihak yang memberikan sesuatu berhak mendapatkan penggantian dari pihak yang diberi. Peserta merasa sudah memberikan premi yang menjadi kewajibannya sehingga ketika mengalami musibah maka peserta juga berharap untuk bisa mendapatkan pertanggungan atas kewajiban yang sudah diberikan kepada pengelola.

Pada produk Asuransi Takaful Umum, kontribusi dibayarkan oleh peserta setiap satu kali dalam setahun sesuai periode polis. Untuk peserta Takaful Indonesia cabang Malang dapat membayarkan kontribusi ke rekening kantor pusat Takaful Indonesia di Surabaya. Cara dan waktu pembayaran ini tercantum pada polis mengenai pembayaran kontribusi yang isinya telah disepakati oleh peserta dan pengelola. Dana kontribusi yang terkumpul ini berfungsi untuk memberikan bantuan kepada setiap peserta yang mengalami musibah, tidak terkecuali peserta yang memberikan dana kontribusi itu sendiri. Nilai dari jumlah pertanggunggan jauh dari nilai kontribusi yang diberikan oleh peserta. Misalnya untuk kontribusi bangunan pada produk Takaful Abror per tahun sebesar Rp. 156.280 dengan nilai manfaat atau pertanggungan sebesar Rp. 108.000.000 dari perumpamaan tersebut dapat dilihat selisih antara jumlah kontribusi dengan 
jumlah premi sangat jauh. Oleh karena itu, ketika terjadi klaim dana yang hanya Rp. 156.280 bisa menjadi Rp. 108.000.000 diambilkan dari pool of tabarru' yang dikumpulkan secara kolektif oleh peserta lain sebagai penanggung. Para peserta yang membayarkan dana kontribusi, sesuai dengan ketentuan fatwa Dewan Syariah Nasional tentang Akad Tabarru' pada Asuransi Syariah dan Reasuransi Syariah yang menyatakan bahwa peserta merupakan penanggung bagi peserta lain.

Kontribusi yang dibayarkan komposisinya terdiri dari ujrah untuk pengelola yang terdiri dari biaya materai dan biaya pembuatan polis; serta dana tabarru'. Dana tabarru' ini yang nantinya akan digunakan untuk menolong peserta lain yang sedang mengalami musibah. Namun, musibah tidak dapat ditentukan kapan akan menimpa seseorang, oleh karena itu kumpulan dana tabarru' yang belum digunakan diinvestasikan oleh pengelola agar lebih produktif, hasil investasinya pun kembali pada dana tabarru' dan akan menambah jumlah dana tabarru' itu sendiri.

Dalam perkembangannya, Takaful Indonesia telah mengalami beberapa pergantian berkaitan dengan pengelolaan dana tabarru'. Pada awalnya akad yang digunakan merupakan akad mudharabah, dimana dana asuransi yang telah terkumpul kemudian diinvestasikan, hasil investasi tersebut kemudian dibagi menjadi dua, sebagian untuk dana cadangan klaim kemudian sebagian lagi untuk operasional perusahaan. Namun, akad ini dirasa masih sama seperti praktik pada asuransi konvensional sehingga kemudian diganti menjadi akad kafalah. Akad wakalah oleh Takaful Indonesia masih dianggap kurang relevan dengan hakikat dari asuransi syariah kemudian diganti menjadi akad wakalah bil ujrah yang digunakan sampai sekarang. Takaful Indonesia menjadi wakil dari para peserta dalam mengelola dana tabarru' melalui akad wakalah dan menjadi wakil dari para peserta dalam mendistribusikan dana tabarru' kepada peserta yang mengalami musibah.

Hal ini dapat dilihat ketika peserta yang tertimpa musibah mengajukan klaim, semua proses dilakukan oleh Asuransi Takaful Umum mulai dari survei sampai pengiriman berkas dan pembayaran kepada bengkel rekanan. Tujuan dari proses-proses tersebut adalah untuk menjaga amanah dari peserta takaful. Praktek yang terdapat pada Takaful Indonesia ini sesuai dengan ketentuan fatwa Dewan Syariah Nasional tentang Akad Tabarru' pada Asuransi Syariah dan Reasuransi Syariah yang menyatakan bahwa Perusahaan asuransi bertindak sebagai pengelola dana hibah, atas dasar akad Wakalah dari para peserta selain pengelolaan investasi.

Andri Soemitra dalam bukunya Bank dan Lembaga Keuangan Syariah menyebutkan bahwa pengelola berhak mendapatkan fee sesuai dengan kesepakatan. Melalui akad wakalah, para peserta memberikan kuasa kepada pengelola untuk mengelola dananya dalam hal, antara lain seperti kegiatan administrasi, pengelolaan dana, pembayaran klaim, underwriting, pengelolaan portofolio risiko, pemasaran dan investasi. ${ }^{r s}$

Mekanisme pengelolaan dana tabarru' menggunakan model wakalah bil ujrah. Peneliti tidak mendapatkan informasi yang akurat mengenai pembukuan maupun pengelolaan dana tabarru'. Hal ini dikarenakan pihak kantor cabang Malang tidak mengetahui detail proses pengelolaan dana tabarru'. Menurut Bapak Mashudi, S.E, "Semua proses pengelolaan dana tabarru' dilakukan oleh kantor pusat PT. Asuransi Takaful Umum, sementara kantor cabang hanya menjadi perantara antara peserta dengan perusahaan asuransi.

Menurut pengamatan peneliti melihat pada publikasi ikhtisar keuangan Takaful Indonesia, pada Asuransi Takaful Umum kontribusi yang dibayarkan peserta langsung masuk pada satu akun yang bernama kontribusi bruto. Setelah dikurangi pendapatan kontribusi untuk pengelola, kumpulan dana kontribusi tersebut diinvestasikan. Hasil investasi dialokasikan untuk cadangan tabarru'untuk klaim dan ujrah untuk pengelola. Hal ini sesuai dengan ketentuan mengenai pengelolaan yang menyatakan bahwa pembukuan dana tabarru' harus terpisah dari dana lainnya, hasil investasi dari dana tabarru' menjadi hak kolektif peserta dan dibukukan dalam akun tabarru', serta dari hasil investasi perusahaan asuransi dapat memperoleh bagi hasil berdasarkan akad mudharabah atau akad mudharabah musyarakah atau memperoleh ujrah (fee) berdasarkan akad wakalah bil ujrah. Praktek wakalah bil ujrah pada Takaful Indonesia, dapat digambarkan seperti model wakalah yang dipakai di Asia Tengah berikut ini: ${ }^{35}$

\footnotetext{
34 Andri Soemitra, Bank, h. 279

35 Muhaimin Iqbal, Asuransi Umum Syariah dalam Praktik, Upaya Menghilangkan Gharar, Maisir dan Riba (Jakarta: Gema Insani, 2006), h. 120.
} 


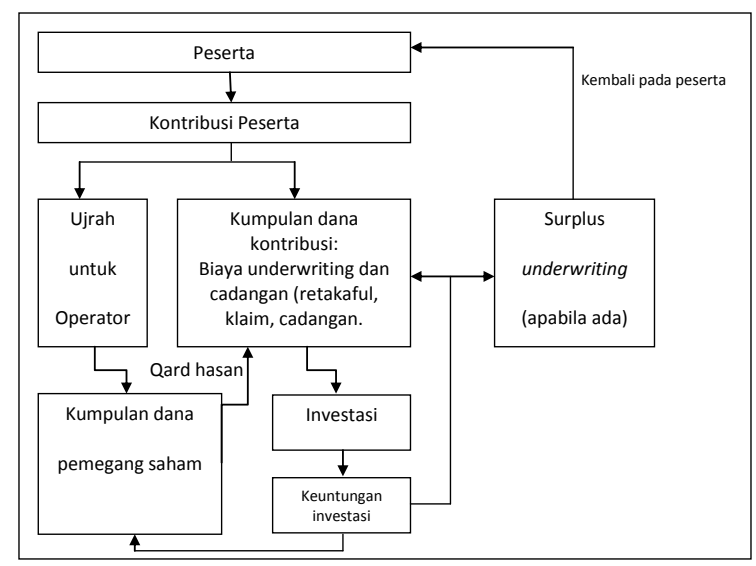

Gambar 1 Wakalah bil Ujrah Model Asia Tengah

Hasil investasi yang dimasukkan pada akun dana tabarru'bisa membuat surplus underwriting terhadap dana tabarru'. Pada Takaful Indonesia, Bapak Ahmad Zainul Hasan, S.H menjelaskan mengenai pembagian surplus underwriting sebagai berikut ${ }^{36}$ :

"Surplus underwriting terhadap dana tabarru' ini kemudian dibagi dan dialokasikan untuk pengelola $60 \%$, untuk peserta $20 \%$ dan untuk cadangan tabarru' yang digunakan ketika ada pengajuan klaim $20 \%$."

Langkah yang diambil oleh Takaful Indonesia sesuai dengan isi dari Fatwa Dewan Syariah Nasional tentang Akad Tabarru' pada Asuransi Syariah dan Reasuransi Syariah, salah satu dari beberapa alternatif yang dapat dilakukan ketika surplus underwriting terhadap dana tabarru', yaitu disimpan sebagian sebagai dana cadangan tabarru' dan dapat dibagikan sebagian lainnya kepada perusahaan asuransi dan para peserta sepanjang disepakati oleh peserta. Tentu peserta telah sepakat karena ketentuan tersebut telah ada pada polis yang disetujui oleh peserta.

Menurut Muhammad Syakir Sula, surplus dana tabarru'dapat dibagikan kembali kepada para peserta sebagai suatu bonus. ${ }^{37}$ Padahal sebenarnya dalam akad tabarru' tidak ada kewajiban bagi pengelola untuk memberikan bonus. Hal ini dikarenakan dana tabarru'tersebut sudah diikhlaskan oleh peserta untuk tujuan tolong menolong. Demikian halnya dengan peserta, tidak berhak untuk meminta bagi hasil dari pengelola. Takaful Indonesia yang mengalokasikan tabarru' untuk pengelola, cadangan tabarru' dan untuk peserta sesuai dengan teori yang dikemukakan oleh Muhammad Syakir Sula.

Dana tabarru' tidak selalu mengalami surplus underwriting, akan tetapi bisa juga terjadi defisit

36 Ahmad Zainul Hasan, Wawancara (Malang, 8 Februari 2012).

37 Muhammad Syakir Sula, Asuransi, h. 227. underwriting karena terlalu banyak klaim yang diajukan. Berdasarkan hasil wawancara dengan Bapak Ahmad Zainul Hasan, S.H beliau menjelaskan bahwa ${ }^{38}$ :

'Pada saat dana tabarru' mengalami defisit underwriting, maka pengelola memberikan pinjaman dengan akad qard hasan yang dananya berasal dari pengelola pusat. Qard hasan merupakan pinjaman yang ketika dikembalikan tidak ada tambahan apapun. Qard hasan ini diambil dari dana cadangan yang memang telah dirancang oleh perusahaan."

Dana qard hasan digunakan untuk menalangi defisit underwriting dana tabarru' sehingga bisa memenuhi klaim. Pinjaman tersebut akan dikembalikan ketika dana tabarru'telah mengalami surplus underwriting.

Praktek yang dilakukan oleh takaful Indonesia dalam mengambil langkah ketika terjadi defisit underwriting pada dana tabarru', sesuai dengan ketentuan fatwa Dewan Syariah Nasional tentang Akad tabarru' pada Asuransi Syariah dan Reasuransi Syariah mengenai defisit underwriting. Pada ketentuan ketentuan tersebut disebutkan bahwa jika terjadi defisit underwriting atas dana tabarru' (defisit tabarru'), maka perusahaan asuransi wajib menanggulangi kekurangan tersebut dalam bentuk qardh (pinjaman) serta pengembalian dana qardh kepada perusahaan asuransi disisihkan dari dana tabarru'.

Suatu perjanjian tidak selalu berjalan sesuai dengan apa yang sudah diperjanjikan. Terkadang pada masa perjanjian berlangsung terjadi permasalahanpermasalahan yang dapat menghambat jalannya perjanjian. Pada Takaful Indonesia, Bapak Ahmad Zainul Hasan, S.H menjelaskan ${ }^{39}$ :

"Biasanya permasalahan yang terjadi pada asuransi merupakan permasalahan yang disebabkan karena adanya klaim yang tidak bisa dibayarkan. Tidak bisa dibayarkan karena syarat-syarat untuk terjadinya klaim tidak sesuai dengan polis yang telah disepakati. Dalam kasus seperti ini perusahaan mempunyai kebijakan, yaitu setelah dilakukan analisa terhadap musibah yang terjadi perusahaan tetap membayarkan klaim, akan tetapi jumlahnya tidak disesuaikan dengan isi polis yang telah disepakati. Alasannya karena peserta telah melanggar dari isi polis itu sendiri. Langkah awal dalam menyelesaikan perselisihan adalah melalui

38 Ahmad Zainul Hasan, Wawancara (Malang, 8 Februari 2012).

39 Ahmad Zainul Hasan, Wawancara (Malang, 8 Februari 2012). 
musyawarah, apabila jalan ini tidak berhasil maka arbitrase atau pengadilan menjadi alternatif untuk menyelesaikan sengketa.".

Langkah yang diambil oleh Takaful Indonesia sesuai dengan fatwa Dewan Syariah Nasional tentang Akad tabarru' pada Asuransi Syariah dan Reasuransi Syariah yang terdapat pada bagian ketujuh mengenai ketentuan penutup. Fatwa tersebut menetapkan bahwa jika salah satu pihak tidak menunaikan kewajibannya atau jika terjadi perselisihan di antara para pihak, maka penyelesaiannya dilakukan melalui Badan Arbitrase Syari'ah setelah tidak tercapai kesepakatan melalui musyawarah.

Dari penjelasan di atas dapat disimpulkan bahwa pada setiap bagian ketentuan dari fatwa Dewan Syariah Nasional tentang Akad tabarru' pada Asuransi Syariah dan Reasuransi Syariah sesuai dengan apa yang menjadi kebijakan dari Takaful Indonesia. Namun, terdapat satu hal yang berbeda antara fatwa dengan realita yang terdapat pada Takaful Indonesia, yaitu mengenai adanya sistem pengembalian dana kontribusi yang telah diberikan ketika perjanjian diputus secara sepihak oleh peserta sebelum periode perjanjian habis. Padahal dana kontribusi yang dipersamakan dengan hibah haram untuk diambil kembali. Meskipun praktek pada Takaful Indonesia sesuai dengan teori yang dikemukakan oleh Muhammad Syakir Sula, seharusnya Takaful Indonesia dalam memberikan pengembalian dana kontribusi memperhatikan aspek hukum Islam sehingga apa yang menjadi kebijakannya tidak menyalahi aturan syariah.

\section{Kesimpulan}

Berdasarkan hasil penelitian dan pembahasan mengenai Pelaksanaan Akad Tabarru' Pada Takaful Indonesia Cabang Malang (Perspektif Fatwa Dewan Syariah Nasional tentang Akad Tabarru' pada Asuransi Syariah dan Reasuransi Syariah), maka dapat ditarik kesimpulan bahwa pelaksanaan akad tabarru' pada Takaful Indonesia cabang Malang sesuai dengan Fatwa Dewan Syariah Nasional tentang Akad Tabarru' pada Asuransi Syariah dan Reasuransi Syariah. Hal ini dapat dilihat pada setiap kebijakan yang dikeluarkan oleh Takaful Indonesia sesuai dengan setiap bagian ketentuan yang terdapat pada Fatwa Dewan Syariah Nasional tentang Akad Tabarru' pada Asuransi Syariah dan Reasuransi Syariah.

Mengenaipengelolaan dana tabarru' kurang dapat dipahami karena Takaful Indonesia cabang Malang merupakan kantor cabang yang tugas utamanya menjadi perantara antara peserta dengan perusahaan dalam membuat polis maupun menangani pengajuan klaim. Pengelolaan dana tabarru' dan pembagian hasil investasinya dilakukan oleh kantor pusat yang terletak di Surabaya. Pada Takaful Indonesia juga terjadi suatu kesenjangan antara teori dengan realita yang terdapat pada Takaful Indonesia, yaitu mengenai adanya sistem pengembalian dana kontribusi yang telah diberikan ketika perjanjian diputus secara sepihak oleh peserta sebelum periode perjanjian habis. Seharusnya tidak boleh ada pengembalian dalam bentuk apa pun karena dana kontribusi yang diberikan oleh peserta dipersamakan dengan hibah. Hibah yang telah diberikan haram untuk diambil kembali karena sifatnya adalah tolong-menolong dengan mengharap ridha Allah SWT. Namun, belum ada kerelaan untuk melakukan tolong menolong belum dapat dicapai karena isi dari pada fatwa tentang Akad Tabarru' pada Asuransi Syariah dan Reasuransi Syariah disebutkan bahwa peserta tidak hanya sebagai penanggung secara kolektif tetapi juga sebagai pihak yang berhak menerima dana tabarru sehingga peserta yang bergabung sebagai peserta asuransi syariah tujuan utamanya adalah untuk dapat di-cover ketika mengalami musibah dari kontribusi yang telah diberikan kepada pengelola, bukan untuk tujuan tolong-menolong.

\section{Saran}

Bagi pengguna jasa asuransi peneliti sarankan untuk menata niatnya agar mengikuti Asuransi Syariah dan Reasuransi Syariah tidak hanya bertujuan untuk mendapatkan kontribusi dari musibah yang akan dialami, melainkan juga menata niat untuk tolong menolong antar sesama umat Islam. Allah telah memerintahkan hambanya untuk tolong - menolong dalam hal kebaikan. Dengan demikian selain mendapatkan dana pertanggungjawaban. Dengan demikian selain mendapatkan dana pertanggungjawaban yang dikehendaki, kegiatan tersebut juga bernilai ibadah.

Bagi para peneliti diharapkan dapat mengembangkan penelitian ini lebih lanjut, dengan menggunakan sudut pandang yang berbeda ataupun hal - hal lain yang lebih perlu lagi diteliti mengenai Asuransi Syariah dan Reasuransi Syariah. Dengan begitu Lembaga - Lembaga Asuransi Syariah dapat berbenah dan berkembang sesuai dengan hukum Islam. 


\section{DAFTAR PUSTAKA}

al-Albani, M. Nashiruddin. Ringkasan Shahih Muslim, diterjemahkan Elly Latifah. cet. IV; Depok: Gema Insani, 2008.

al-Asqalani, Ibnu Hajar. Fathul Baari Syar Shahih Al Bukhari, diterjemahkan Amiruddin, Penjelasan Kitab Shahih Al Bukhari. Buku 14; Jakarta: Pustaka Azzam, 2005.

Ali, Zainuddin. Hukum Asuransi Syariah. Jakarta: Sinar Grafika, 2008.

Amin, Ma'ruf. Solusi Berasuransi: Lebih Indah dengan Syariah. Jakarta: Salamadani, 2009.

Amiruddin dan Zainal Asikin. Pengantar Metode Peneltian Hukum. Jakarta: Rajawali Press, 2006.

Departemen Agama RI. Al-Qur'an dan Terjemahannya Juz 1 - Juz 30. Surabaya: Al-Hidayah, 1998.

Fatwa Dewan Syariah Nasional No.53/DSN-MUI/ III/2006 tentang Tabarru' Pada Asuransi Syariah dan Reasuransi Syariah.

Fatwa Dewan Syariah Nasional No. 21/DSN-MUI/ $\mathrm{X} / 2001$ tentang Pedoman Umum Asuransi Syariah.

Himpunan Fatwa Dewan Syariah Nasional.

Iqbal, Muhaimin. Asuransi Umum Syariah dalam Praktik, Upaya Menghilangkan Gharar, Maisir dan Riba. Jakarta: Gema Insani, 2006.

Moleong, Lexy J. Metode Penelitian Kualitatif, Edisi
Revisi. Bandung: PT Remaja Rosdakarya, 2005.

Nasution, Bahder Johan. Metode Penelitian Hukum. Bandung: Mandar Maju, 2008.

Produk, www.takaful.com, diakses tanggal 15 Februari 2012.

Qardhawi, Yusuf. al-Halal wal-haram fil-Islam, diterjemahkan Abu Sa'id al-Falahi dan Aunur Rafiq Shaleh Tamhid. Cet. I; Jakarta: Rabbani Press, 2000.

Risk Managemenet in Islam-Takaful, www.islamicworld.net, diakses tanggal 13 Mei 2011.

Sejarah Asuransi Syariah di Indonesia, www. asuransisyariah.net, diakses tanggal 19 Oktober 2011.

Sekilas Takaful Indonesia, www.takaful.com, diakses tanggal 19 Oktober 2011.

Soemitra, Andi. Bank Dan Lembaga Keuangan Syariah, Cetakan ke-2. Jakarta: Prenada Media Grup, 2009.

Soekanto, Soerjono. Pengantar Penelitian Hukum. cet. Ke-3. Jakarta: UI Press, 1986.

Sula, Muhammad Syakir. Asuransi Syariah (Life And General): Konsep Dan System Operasional. cet.1. Jakarta: Gema Insani Press, 2004.

Visi dan Misi, www.takaful.com diakses tanggal 7 Maret 2012. 